Web Jurnal Online: jurnal.unmuhjember.ac.id

By: Salmawati; Dian Eka Rahmawati; Anang Setiawan

The Role of Argomoulyo Village Samsat in Breaking Taxpayer Density in Bantul KPPD 2017-2018

\title{
The Role of Argomoulyo Village Samsat in Breaking Taxpayer Density in Bantul
}

$$
\text { KPPD } 2017-2018
$$

\author{
Salmawati $^{1}$, Dian Eka Rahmawati ${ }^{2}$, Anang Setiawan ${ }^{3}$ \\ ${ }^{1}$ Student Master of Government Affairs and Administration, Universitas Muhammadiyah \\ Yogyakarta, Indonesia, email; salmawatisalma43141004@yahoo.co.id \\ ${ }^{2}$ Lecturer Master of Government Affairs and Administration, Universitas \\ MuhammadiyahYogyakarta, Indonesia, email; dianekarahmawati93@gmail.com \\ ${ }^{3}$ Student Master of Government Affairs and Administration, Universitas \\ MuhammadiyahYogyakarta, Indonesia, email; ananggsetiawan2016@gmail.com
}

\begin{abstract}
The problem of paying taxes is the responsibility of Samsat. Bantul has a Regional Tax Service Office which is responsible for the implementation of the Samsat. The Main Samsat of Bantul has problems in queuing taxpayers who are challenging to decipher, and the targeted tax nominal has also not met the nominal that must be realized. This has become a conversation in the National Police Corruption. In 2017 the National Police Corlantas initiated the existence of a helper Samsat with the name Samsat desa. Samsat Desa was inaugurated in 2017 and Yogyakarta became a pilot city for the construction of village Samsat. Village Samsat is an auxiliary Samsat at the village or kelurahan level. Village Samsat is formed to bring taxpayers closer to Samsat services so that taxpayers do not have to travel long distances to the main Samsat. The type of research chosen in this study is qualitative, which is intended as a type of research whose findings are not obtained through statistical procedures or other forms of calculation. Then the types of data taken are primary and secondary. Data collection techniques used are interviews, observation, documentation, and literature. The data analysis unit in this study was the head and staff of the Bantul Regency KPPD, Argomulyo Village Samsat staff, and 10 Argomulyo Village Samsat visitors, totaling 20. The results of this research were the role of Argomulyo Samsat Village in breaking down taxpayers in Bantul Central Samsat and prove that during the one year of the implementation of the Samsomulyo village Samsat, it can reduce the queue of taxpayers in the Main Samsat of Bantul. So that in 2018, payments in the Bantul KPPD become more organized, and taxpayers do not jostle or wait for very long service times. In conclusion, the implementation of village Samsat can be said to be successful because Argomulyo Village Samsat is considered to be able to reach the surrounding community and receive motor vehicle tax of $\mathrm{Rp} 656,813,500.00$ with 1,905 motorized vehicles paying the fee. The socialization of the Argomulyo Village Samsat in collaboration with Spot Radio, Radio Persatuan Bantul, TV Persatuan Bantul and the website of the Village of Argomulyo. This socialization had a positive impact on the development of village Samsat, and the community satisfaction index, Argomulyo Village Samsat scored 78.87 and was classified as useful.
\end{abstract}

\section{Keywords: Samsat, Service Innovation, Argomulyo, Bantul}




\section{INTRODUCTION}

The problem of paying taxes that are not timely has become a bad culture in Indonesia. This resulted in the hindrance in the construction of infrastructure or public facilities, which the source of the budget came from the payment of taxes, especially local taxes. In Indonesia, four types of fees must be obeyed by every citizen of Indonesia. The four examples of charges include Income Tax (PPh), Land and Building Tax (PBB), Road Lighting Tax, and Motor Vehicle Taxes. The tax payment is mandatory and must be paid on time. If not paid on time, there are sanctions given by the government to taxpayers.

One type of tax included in the regional fee is motor vehicle tax, which is a tax on ownership and or control of motorized vehicles (Law Number 28 of 2009). Under the established law, the subject of this motor vehicle tax is individuals or entities that own motorized vehicles. The basis of the imposition of motorized vehicle tax takes into account the selling value of motorized vehicles and the weight that can later reflect the relationship with the level of road damage and environmental pollution caused by the use of these motorized vehicles.

Some Indonesian people use motorized vehicles to travel, for example, the streets in the Special Region of Yogyakarta have experienced a density of motorized cars that cause congestion. This is due to the importance of motorized vehicles for modern society. According to (Sukirno, 1995) in a modern society transportation transportation has two functions, namely (a) As a mode tool, which is transporting people from home to work or place of business and (b) As final goods, namely fulfilling the community's need for transportation services by the transportation system is provided with city transportation facilities to support population activities in economic activities. The increase in motorized vehicles is not directly proportional to public order in paying motorized taxes. The disorder of society, especially in Bantul Regency, Yogyakarta Special Region in paying motorized taxes, is influenced by factors, one of which is the location of the main Samsat. So that people have to travel a considerable distance to pay taxes. A further consideration is that there is often a long queue in the main Samsat, so people tend not to have time to wait for hours in paying taxes.

This is an obstacle for the One-Stop Single Unit Administration or Samsat and the police apparatus, namely the National Police Corruption Eradication Unit related to the disorder of society is paying taxes which will have an impact on reducing tax revenues each year. Of course, with this problem, the National Police Corruption Eradication Unit immediately turned the brain in dealing with this by providing innovation as a solution to overcome some of the factors in late tax payments.

These problems are positively responded to by the National Police Corruption by setting public policies in the form of village samsat development in each subdistrict in the Special Region of Yogyakarta as an alternative solution. Previously esamsat and Samsat Drive Thru have been launched, but there are still many flaws in their implementation such as servers that are often erroneous. However, both 
Web Jurnal Online: jurnal.unmuhjember.ac.id

By: Salmawati; Dian Eka Rahmawati; Anang Setiawan The Role of Argomoulyo Village Samsat in Breaking Taxpayer Density in Bantul KPPD 2017-2018

innovations continue to be carried out along with changes in the form of village samsat to continue to improve the existing system.

In addition to decisions in making public policies, public government services are also essential to be included in the practice of public policy. In the tradition of mobile tax payment services in Samsat, the Regional Tax Service Office, BPD DIY, the police, and Jasa Raharja are fully responsible facilitators. Village Samsat is an annual service registration for STNK in the form of motor vehicle tax payments that are implemented at the kelurahan office for the municipal level and village hall for the district level.

Village Samsat services prioritize villages that are far from the main Samsat service office. Currently, village Samsat already exists in 5 communities in Yogyakarta. The five towns are in Pakem Binangun (Sleman Regency), Bambang Lipuro (Bantul), Semugih (Gunungkidul), Palihan (Kulon Progo) and Wirogunan (City of Yogyakarta). While for the Bantul Regency phase I, Argomulyo Village, Sedayu, Bantul, Sidomulyo Village, Bambanglipuro District, which covers the Sumber Mulyo Village area, Mulyodadi Village, Pudong District. Phase II of Bantul Regency, Imogiri Village, Imogiri Subdistrict, which includes the cities of Girirejo Selopamioro, Sriharjo, Wukirsari, and Dlingo Districts. (http://web.jogjaprov.go.id/warga/catatan-sipil/view/samsat-desa-inovasi-layanankesamsatan, diakses pada 28 Juni 2018)

The village Samsat is delightful to study because it is a pilot project. This research took the location of Argomulyo Village Samsat, Bantul Regency which had become one of the pilot villages Samsat. The Samsomulyo Village Samsat has a website assisted by the local town in its operation. Looking from above, the researcher wants to formulate a problem about:

a. How is the role of Samsat Argomulyo Village, Bantul Regency in 2017-2018 in increasing motor vehicle tax?

b. How is the Bantul Regional Tax Office as a One-Stop Single Administration System with partners in socializing the Samsat Desa as an innovation for mobile tax payments?

\section{METODOLOGI}

The approach used in this research is qualitative research with descriptive research types. By the problems and subject matter carried out in this study related to the variables to be studied, namely the Role of Argomoulyo Village Samsat in Breaking Taxpayers' Density in Bantul KPPD 2017 - 2018. Argomulyo in the service of paying the motorized tax within one year. To facilitate analyzing the data, the authors provide limits and measuring instruments to answer the research problem. In this study, the indicators and parameters of Role Theory, Indicators, and Parameters of Public Policy Theory, Indicators and Parameters of Public Service Theory refer to. While the measuring instruments in this study include: 
Web Jurnal Online: jurnal.unmuhjember.ac.id

By: Salmawati; Dian Eka Rahmawati; Anang Setiawan

The Role of Argomoulyo Village Samsat in Breaking Taxpayer Density

in Bantul KPPD 2017-2018

\section{a. Role Theories and Parameters}

Table 2.1

Role Theories and Parameters

\begin{tabular}{|l|l|}
\hline \multicolumn{1}{|c|}{ Indicator } & \multicolumn{1}{c|}{ Parameter } \\
\hline Ideal role & $\begin{array}{l}\text { a. Carry out obligations according to community } \\
\text { assumptions. }\end{array}$ \\
\hline Role that is considered by oneself & b. Meet the expectations of the community. \\
\hline The role that is carried out or done & $\begin{array}{l}\text { a. Able to play a role in any situation and not } \\
\text { tarnish the good name of the group. }\end{array}$ \\
\hline
\end{tabular}

\section{b. Indicators and Parameters of Public Policy Theory}

Table 2.2

. Indicators and Parameters of Public Policy Theory

\begin{tabular}{|l|l|}
\hline \multicolumn{1}{|c|}{ Indicator } & \multicolumn{1}{c|}{ Parameter } \\
\hline Interest that affects & $\begin{array}{l}\text { The involvement of individuals or groups who } \\
\text { have the same goals. }\end{array}$ \\
\hline Benefit type & Bringing positive change. \\
\hline Degree of change to be achieved & a. Clear target achievement. \\
\hline Location of decision making & b. The amount of target to be achieved. \\
\hline Program executor & Speed and accuracy of decision making \\
\hline Resources used & Program implementing competencies \\
\hline
\end{tabular}

\section{c. Public Policy Establishment of Village Samsat}

Table 2.3

Public Policy Establishment of Village Samsat

\begin{tabular}{|l|l|}
\hline \multicolumn{1}{|c|}{ Indicator } & \multicolumn{1}{c|}{ Parameter } \\
\hline Interest that affects & $\begin{array}{l}\text { The involvement of individuals or groups who } \\
\text { have the same goals. }\end{array}$ \\
\hline Benefit type & Bringing positive change. \\
\hline Degree of change to be achieved & a. Clear target achievement. \\
\hline Location of decision making & b. The amount of target to be achieved. \\
\hline Program executor & Speed and accuracy of decision making \\
\hline Resources used & Program implementing competencies \\
\hline
\end{tabular}

To focus on the research location, the location taken was Argomulyo Village Samsat, Sedayu District, Bantul Regency, Special Region of Yogyakarta. The technique of collecting data is done by the method of Interview, Observation, and Documentation. Data analysis techniques through a qualitative approach as initiated by Miles and Huberman also take into account other relevant strategies such as Grounded Theory. To strengthen the author's analysis techniques, the Strauss and Corbin (2013) approach is also used, namely through several procedures as follows: (1) Encoding/subtraction; (2) thematization; (3) determine the storyline; (4) developing the storyline and theorizing; (5) 
Web Jurnal Online: jurnal.unmuhjember.ac.id

By: Salmawati; Dian Eka Rahmawati; Anang Setiawan The Role of Argomoulyo Village Samsat in Breaking Taxpayer Density in Bantul KPPD 2017-2018

analysis by linking themes to available theoretical theories and / or looking for relationships with other items; (6) conclusions are only part of the complete configuration stage. During this study did not ignore verification. Verification means asking the storyline again in mind, reviewing field notes related to data, conclusions, and a series of other field findings data.

\section{RESULTS AND DISCUSSION}

\subsection{The Role of Village Samsat in Increasing Motor Vehicle Taxes}

The Regional Tax Service Office or the One-Stop Manunggal One-Stop Unit seeks to control mobile tax payments with several attempts. One of them is by forming a village Samsat. Do not stop at the formation of village samsat only. The efforts of the town Samsat to be known to the public and to make it easier for the public to pay taxes became important in supporting the growth of the city Samsat.

\subsubsection{Importance of Forming Village Samsat}

The establishment of the parent Samsat auxiliary office is critical, given the number of motorized vehicles that are increasing every year. The National Police Corps and Regional Tax Service Offices or their parts commonly referred to as the One-Stop Single Administration Unit has innovated to form Samsat auxiliary offices in the form of village Samsat, especially in villages or urban villages in the Special Region of Yogyakarta. In 2017-2018 the number of motorized vehicles had increased, this must be directly proportional to public order in paying taxes so that taxes can be a contribution of the community to development carried out by the government. The following are data on the number of motorized vehicles in the regions of Bantul Regency in 2017 and 2018.

Table 3.1

\begin{tabular}{|c|c|c|c|c|c|}
\hline \multicolumn{6}{|c|}{ Total Vehicles Registered } \\
\hline \multicolumn{6}{|c|}{ In Kppd Bantul Th.2017 } \\
\hline No. & Type & Black & Yellow & Red & Total \\
\hline 1 & 2 & 3 & 4 & 5 & 6 \\
\hline 1 & Sedan & 6.491 & 75 & 12 & 6.578 \\
\hline 2 & Jeep & 3.228 & & 16 & 3.244 \\
\hline 3 & Mini bus & 35.320 & 49 & 368 & 35.737 \\
\hline 4 & Bus / Microbus & 232 & 577 & 19 & 828 \\
\hline 5 & Pick Up & 9.003 & 8 & 48 & 9.059 \\
\hline 6 & Light truck & 3.317 & 413 & 39 & 3.769 \\
\hline 7 & Truck & 127 & 186 & 3 & 316 \\
\hline 8 & Motorcycle & 363.217 & & 1.335 & 364.552 \\
\hline & Total & 420.935 & 1.308 & 1.840 & 424.083 \\
\hline
\end{tabular}

Reference : Data Olah Kantor Pelayanan Pajak Daerah Bantul 
Web Jurnal Online: jurnal.unmuhjember.ac.id

By: Salmawati; Dian Eka Rahmawati; Anang Setiawan The Role of Argomoulyo Village Samsat in Breaking Taxpayer Density in Bantul KPPD 2017-2018

Table 3.2

\begin{tabular}{|c|c|c|c|c|c|}
\hline & Total & ehicles & Register & & \\
\hline & In Kppd Ban & ll Th.20 & 18 (S.D. & Octobe & \\
\hline No. & Type & Black & Yellow & Red & Total \\
\hline 1 & 2 & 3 & 4 & 5 & 6 \\
\hline 1 & Sedan & 7.237 & 75 & 12 & 7.324 \\
\hline 2 & Jeep & 3.698 & & 19 & 3.717 \\
\hline 3 & Mini bus & 41.567 & 49 & 394 & 42.010 \\
\hline 4 & Bus / Microbus & 283 & 663 & 20 & 966 \\
\hline 5 & Pick Up & 10.067 & 9 & 58 & 10.134 \\
\hline 6 & Light truck & 3.713 & 453 & 39 & 4.205 \\
\hline 7 & Truck & 136 & 189 & 3 & 328 \\
\hline 8 & Motorcycle & 396.189 & & 1.435 & 397.624 \\
\hline & Total & 462.890 & 1.438 & F1.980 & 466.308 \\
\hline
\end{tabular}

Reference : Data Olah Kantor Pelayanan Pajak Daerah Bantul

In the table above it can be proven that motorized vehicles in Bantul Regency have increased by 42,225 units of vehicles for all types of vehicles, including three kinds of vehicle plate colors, namely yellow, black, and red from 2017 to 2018. Must be directly proportional to the increase in the amount of motor vehicle tax. So from that Bantul Regional Tax Service Office needs to add an auxiliary Samsat office to help serve taxpayers with a substantial amount.

\subsubsection{Efforts of Argomulyo Village Samsat in Increasing Motor Vehicle Taxes}

\section{a. Socialization}

After the village Samsat was inaugurated including the Samsomulyo Village Samsat, the socialization continued to be carried out by the Samsat organizers so that the town Samsat, especially the Argomulyo Village Samsat, could be better known to the public. Warih Budiyono stated this as Samsat staff in the bookkeeping and billing section:

"Sosialisasi dilakukan dengan berita di surat kabar, radio, dan bertemu dengan kelurahan serta kecamatan dalam forum pertemuan sosialisasi, dan tidak lupa membuat spanduk dan banner."

In addition, the way to socialize Argomulyo Village Samsat is also carried out in the following manner, as stated by Winardi as Head of Registration and Determination Section: 
Web Jurnal Online: jurnal.unmuhjember.ac.id

By: Salmawati; Dian Eka Rahmawati; Anang Setiawan The Role of Argomoulyo Village Samsat in Breaking Taxpayer Density in Bantul KPPD 2017-2018

\begin{abstract}
Sosialisasi dilakukan dengan penyiaran di Radio Persatuan di Bantul, serta iklan tentang samsat desa yang ditampilkan di stasiun televisi Persatuan di Bantul."
\end{abstract}

Broadcasting on the radio is not just advertising, but Samsat officially holds a talk show, which usually works with Spot Radio. This talk show discusses everything about the whole Samsat. And considering the new regulations in Samsat, including innovations in the form of the addition of the main Samsat auxiliary office called the village Samsat.

\title{
Collaboration with Argomulyo Village Devices
}

Collaboration with village officials is related to the rental of the village Samsat office. This is highly considered by the Bantul Regional Tax Service Office to optimize community outreach. Winardi conveyed this as the staff of the Head of the Bantul KPPD Registration and Determination Section:

"Pemilihan lokasi Samsat desa dilakukan dengan memilih desa atau kelurahan yang memiliki keadaaan tempat yang strategis dan mencari tempat yang dapat menjangkau beberapa wilayah. Desa yang dipilih diutamakan yang telah memiliki peraturan desa yang jelas. Kemudian masalah sewa tempat dibahas lebih lanjut dengan melakukan perjanjian dengan desa atau kelurahan yang bersangkutan."

Clear village regulations are used as a benchmark for rental prices to be paid by the Regional Tax Service Office for one year. Darmasto delivered the discussion of the rental rate for the Argomulyo Samsat Village as the Head of the Bantul KPPD Administration Section:

"Harga sewa kantor Samsat Desa Argomulyo sebesar enam juta rupiah. Nominal ini sudah ditentukan oleh Peraturan Desa Argomulyo. Tidak hanya di Samsat Desa Argomulyo saja, Samsat Desa Bambang Lipuro juga menyewa kantor desa dengan harga enam juta rupiah pertahunnya."

The specified rental prices are adjusted to the Argomulyo Village Regulations, where Argomulyo Village itself supports the establishment of village Samsat. It was marked by the support of socializing the village Samsat on the Argomulyo Village website. Articles on village Samsat are posted on the site by providing some vital information to villagers about the services to be provided by Samsat in Argomulyo village. The appearance of the Argomulyo Village website is as follows. 


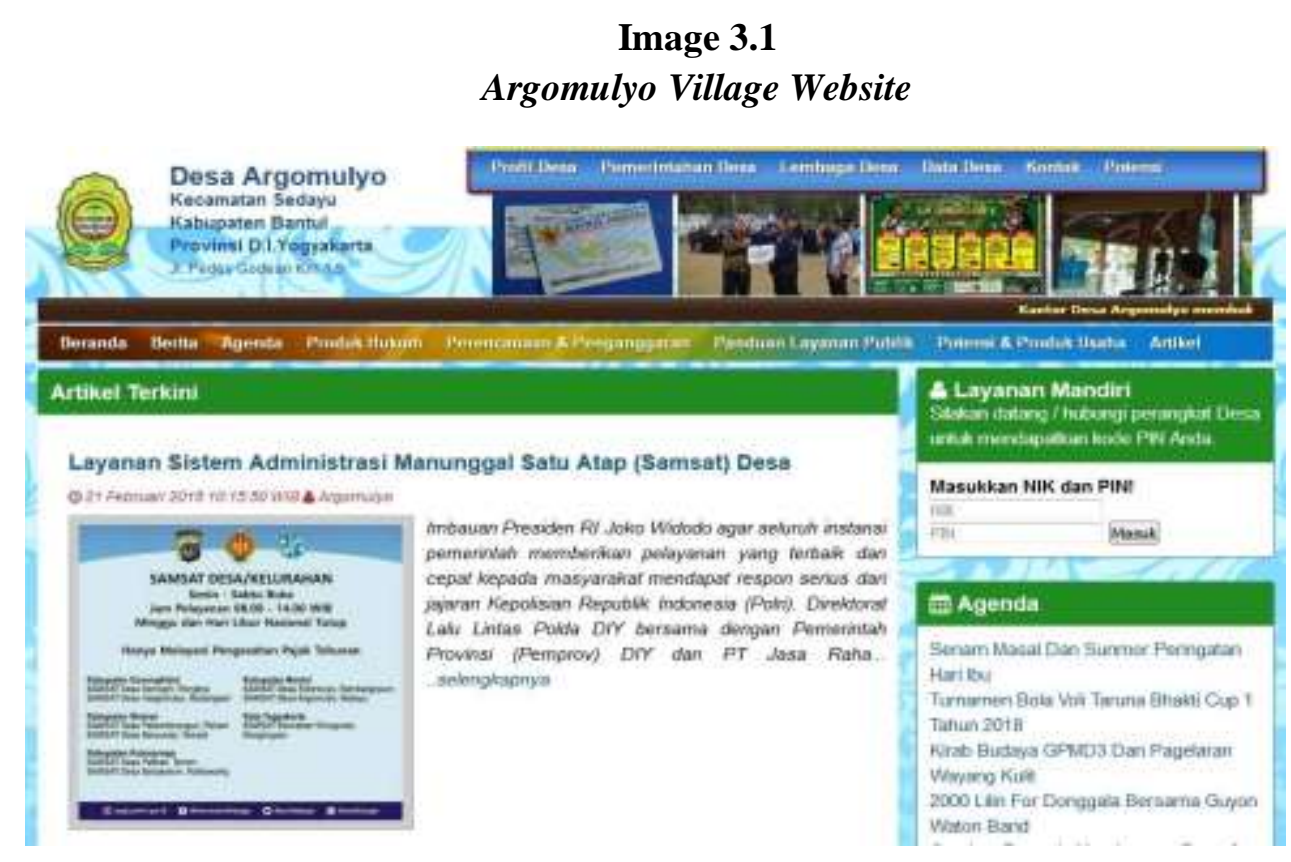

Reference : http://argomulyo.bantulkab.go.id

\subsubsection{Reach Area and Strategic Location of Samsat Argomulyo Village}

Village Samsat was established in several villages, in the Special Region of Yogyakarta. Each community Samsat has a range of each region that is intended to be able to reach local people who need to pay taxes, so they do not have to go to the main Samsat or village Samsat which is located far away. Argomulyo Village Samsat itself has coverage of the service area of Argomulyo Village, Sedayu and its surroundings, Gamping, Godean, and its environs, Sentolo and its surroundings. The area coverage is quite extensive, but Argomulyo Village Samsat also opens online services to make it easier for taxpayers who do not have time to visit the Samsom of Argomulyo Village.

\subsubsection{Increase in Motor Vehicle Taxes}

\section{a. Bantul KPPD Tax Revenue}

The Bantul Regional Tax Service Office continues to increase the amount of tax because the number of motorized vehicles in Bantul Regency is rising every year. Every month, the Bantul Regional Tax Service Office monitors the flow of charges by making a recap of the tax amount. Tax receipts at the Bantul Regional Tax Service Office before the establishment of the village Samsat in 2017 are as follows. 
Page 628-646 ISBN: 978-602-6 988-75-1

Web Jurnal Online: jurnal.unmuhjember.ac.id

By: Salmawati; Dian Eka Rahmawati; Anang Setiawan

The Role of Argomoulyo Village Samsat in Breaking Taxpayer Density in Bantul KPPD 2017-2018

Table 3.3

Tax Revenue in Bantul KPPD 2017

\begin{tabular}{|c|c|c|c|c|}
\hline \multirow{2}{*}{ Month } & \multirow{2}{*}{ Target } & \multicolumn{2}{|c|}{ Realization } & \multirow{2}{*}{ Total } \\
\hline & & Principal & Fine & \\
\hline January & Rp 135.680.000.000 & Rp 12.941.864.000 & Rp 849.063.700 & Rp 13.790.927.700 \\
\hline February & Rp 135.680.000.000 & Rp 24.047.736.300 & Rp 1.508.518.600 & Rp 25.556.254.900 \\
\hline March & Rp 135.680.000.000 & $\operatorname{Rp} 36.670 .774 .700$ & $\operatorname{Rp} 2.354 .856 .100$ & Rp 39.025.630.800 \\
\hline April & Rp 135.680.000.000 & $\operatorname{Rp} 47.872 .068 .800$ & Rp 3.052.436.500 & Rp 50.924.505.300 \\
\hline May & Rp 135.680.000.000 & Rp 60.220.271.900 & Rp 3.868.180.200 & $\mathrm{Rp} 64.088 .452 .100$ \\
\hline June & Rp 135.680.000.000 & $\operatorname{Rp} 65.247 .655 .200$ & $\mathrm{Rp} 4.155 .559 .000$ & Rp 69.403.214.200 \\
\hline July & Rp 135.680.000.000 & $\operatorname{Rp} 83.441 .904 .900$ & Rp 5.395.131.900 & Rp 88.837.036.800 \\
\hline August & Rp 135.680.000.000 & Rp 97.265.496.700 & $\operatorname{Rp} 6.362 .491 .300$ & Rp 103.627.988.000 \\
\hline September & Rp 135.680.000.000 & Rp 110.146.855.000 & Rp 7.294.035.600 & Rp 117.440.890.600 \\
\hline October & Rp 142.399.029.376 & Rp 124.100.608.800 & $\mathrm{Rp} 8.278 .032 .700$ & Rp 132.378.641.500 \\
\hline November & Rp 142.399.029.376 & Rp 137.416.438.100 & Rp 9.306.488.100 & Rp 146.722.926.200 \\
\hline December & Rp 142.399.029.376 & Rp 150.004.111.500 & Rp 10.236.914.600 & Rp 160.241.433.600 \\
\hline
\end{tabular}

\section{Reference : Data olah KPPD Bantul 2017}

From the recapitulation of the amount of tax in the Regional Tax Service Office in 2017 obtained some information about the progress or increase in the amount of tax, namely in January to September the targeted tax amounted to Rp 135,680,000,000.00 but in January the number reached was still very far from the target namely Rp. 13,790,927,700.00. Then in October, the target was raised to Rp 142,399,029,376.00, and an amount that was close to the target was reached, which was Rp 132,378,641,500.00. The target of November and December is still the same, and the achievement of the amount of tax is getting closer to the target, even able to exceed the target in November which is $\mathrm{Rp}$ 146,722,926,200.00 and December amounting to Rp 160,2241,433,600.00. 
Web Jurnal Online: jurnal.unmuhjember.ac.id

By: Salmawati; Dian Eka Rahmawati; Anang Setiawan The Role of Argomoulyo Village Samsat in Breaking Taxpayer Density in Bantul KPPD 2017-2018

\section{b. SAMSAT Tax Receipt Argomulyo Village}

The main Samsat of Bantul Regency will directly input each 1-year tax receipt in Samsomulyo Village Samsat or commonly called the Regional Tax Service Office so that the amount of tax data is processed directly by the Bantul KPPD. The recapitulation of tax revenues in the Samsomulyo Village Samsat is as follows.

Table 3.4

Tax receipts at SAMSAT Argomulyo Village 2017 - 2018

\begin{tabular}{|c|c|c|c|c|c|c|}
\hline Years & Mouth & PKB & SWDKLLJ & Bea Sah & Total & $\begin{array}{r}\text { Total } \\
\text { WP }\end{array}$ \\
\hline 2017 & December & $\operatorname{Rp} 89.401 .200$ & Rp 15.451.000 & Rp 8.000.000 & Rp 112.852.200 & 291 \\
\hline \multirow{12}{*}{2018} & January & $\operatorname{Rp} 373.118 .900$ & Rp 56.966.000 & Rp 29.150.000 & Rp 459.234.900 & 1.032 \\
\hline & February & $\operatorname{Rp} 343.861 .400$ & Rp 54.996.500 & Rp 29.050.000 & $\operatorname{Rp} 427.907 .900$ & 1.029 \\
\hline & March & Rp 384.917.400 & $\operatorname{Rp} 69.310 .000$ & Rp 18.200.000 & Rp 472.427 .400 & 1.351 \\
\hline & April & $\operatorname{Rp} 400.987 .800$ & $\operatorname{Rp} 66.288 .500$ & 0 & $\mathrm{Rp} 467.276 .300$ & 1.199 \\
\hline & May & Rp 460.850 .400 & $\mathrm{Rp} 73.556 .000$ & 0 & Rp 534.406.400 & 1.352 \\
\hline & June & $\mathrm{Rp} 447.055 .700$ & Rp 67.713.000 & 0 & Rp 514.768.700 & 1.208 \\
\hline & July & $\operatorname{Rp} 471.169 .100$ & $\operatorname{Rp} 73.361 .000$ & 0 & Rp 544.530.100 & 1.407 \\
\hline & August & $\operatorname{Rp} 445.073 .900$ & Rp 73.610.500 & 0 & Rp 518.684.400 & 1.422 \\
\hline & September & Rp 523.424.500 & Rp 82.174.000 & 0 & Rp 605.598.500 & 1.527 \\
\hline & October & Rp 528.296.500 & Rp 91.224.500 & 0 & Rp 619.521.000 & 1.729 \\
\hline & November & Rp 566.661.500 & Rp 93.802.000 & 0 & Rp 660.463 .500 & 1.725 \\
\hline & December & Rp 602.183 .600 & Rp 93.074.000 & 0 & $\mathrm{Rp} 656.813 .500$ & 1.905 \\
\hline
\end{tabular}

Reference : Data olah KPPD Bantul 2018

Samsat received a good response from the community, especially the Argomulyo, Sedayu, Gamping, and surrounding communities. This is indicated by an increase in the number of visitors or taxpayers who pay taxes in the form of 1-year extension tax. Of course, the rise in the name of taxpayers also marks an increase in the nominal charge received by the Samsomulyo Village Samsat. Until December 2018, the number of motorized vehicles that have paid taxes is 1,905 , with the amount of motor vehicle tax receipts amounting to $\mathrm{Rp} 602,183,600.00$.

\section{The Role of Village Samsat in Decomposing Taxpayer Density in Bantul KPPD \\ 4.1.1 Distribution of Types of Services for Parent Samsat and Village Samsat}

\section{a. Types of Services for Parent Samsat}

The main Samsat is the central samsat which is used to pay for all types of motor vehicle tax, which includes one-year renewal, five years renewal, registration of new vehicles, transfer of vehicles in and out of the region, replacement of vehicle registration lost. All types of taxes have each requirement that must be met. The following are the types of fees in the parent Samsat along with the elements: 
Web Jurnal Online: jurnal.unmuhjember.ac.id

By: Salmawati; Dian Eka Rahmawati; Anang Setiawan The Role of Argomoulyo Village Samsat in Breaking Taxpayer Density in Bantul KPPD 2017-2018

\section{a) 1 year renewal}

Fill in the SPTPD blank and carry an identity card such as KTP, SIM, KK, passport, original STNK and photocopy, original BPKB and photocopy, and proof of final tax settlement.

\section{b) 5-year renewal}

Fill in the SPTPD blank, check the physical vehicle, carry an identity card such as KTP, SIM, KK, passport, original STNK and photocopy, original $\mathrm{BPKB}$ and fotoki, as well as proof of final tax settlement.

\section{c) Registration of new vehicles}

Fill in the SPTPD form, check the physical vehicle, carry the KTP identity card, invoice, type certificate and type registration sign, car body certificate (specific vehicle), certificate from the Transportation Agency, receipt of purchase of motorized vehicles, NIK (Motor Vehicle Identification Number).

\section{d) Mutation vehicles from outside the area}

Fill in the SPTPD blank, check the physical vehicle, carry an identity card such as KTP, SIM, KK, passport, transfer certificate (substitute for STNK), original BPKB and photocopy, fiscal certificate between the region and receipt.

\section{e) Mutation vehicles from within the region}

Fill in the SPTPD blank, check the physical vehicle, carry an identity card such as KTP, SIM, KK, passport, vehicle registration, original BPKB and photocopy, last year SKPD, purchase receipt.

\section{f) STNK replacement is lost}

Reports of losses from the nearest police force, radio and newspaper advertisements, vehicle physical checks, BPKB, identity (KTP), loss statements were stamped with Rp. 6,000, and lost SNKs could be processed 14 days after the vehicle registration was reported. (Profile of the Regional Tax Service Office in Bantul Regency, Revenue, Financial and Asset Management, Special Region of Yogyakarta) 
Web Jurnal Online: jurnal.unmuhjember.ac.id

By: Salmawati; Dian Eka Rahmawati; Anang Setiawan The Role of Argomoulyo Village Samsat in Breaking Taxpayer Density in Bantul KPPD 2017-2018

\subsubsection{Types of Services for Village Samsat}

Village Samsat has one main task, namely to serve a 1-year renewal of motorized vehicles. This is enough to help the main Samsat in deciphering the density of the queues found in the main Samsat because every day there are a lot of taxpayers who renew one year. With the existence of the village Samsat, the assignment was distributed in the town Samsat.

Requirements that must be taken to replace 1 year in the city Samsat are to fill in the blank, show an identity card (KTP, SIM, KK, passport), show the original STNK and photocopy.

All village Samsat activities are monitored online by the parent samsara. So that the data on the number of payers every minute, hour, and the day is always updated. Then the registration entered the central system in the main Samsat.

\subsubsection{Service Mechanism}

\section{a. 1 Year Tax Payment Mechanism}

\section{Requirements}

To make 1 year tax payment is to bring the original vehicle registration and some personal identities as follows:

a) Individual: Valid self-identity (KTP, SIM, Passport) and for those who are unable to attach sufficient stamped power of attorney.

b) Legal entity: A copy of the deed of establishment, domicile statement, stamped power of attorney sufficiently signed by the leader and affixed with the stamp of the legal entity concerned.

c) Government agencies (including BUMN and BUMD): Letter of assignment or sufficiently sealed power of attorney signed by the leader and affixed with the stamp of the relevant agency. 
Web Jurnal Online: jurnal.unmuhjember.ac.id By: Salmawati; Dian Eka Rahmawati; Anang Setiawan The Role of Argomoulyo Village Samsat in Breaking Taxpayer Density in Bantul KPPD 2017-2018

\section{Systems, Mechanisms and Procedures}

a) Registration and stipulation: Taxpayers or motorized vehicle owners submit requirements to the registration section to be examined and stipulated the amount of PKB and SWDKLLJ

b) Make corrections to PKB and SWDKLLJ stipulations.

c) Payment and submission: Taxpayers or motorized vehicle owners pay PKB and SWDKLLJ to payment officers in accordance with the amount of stipulation. The owner of a motorized vehicle receives an approved STNK, proof of PKB and SWDKLLJ payment as well as SWDKLLJ fund card stickers.

Image 3.1

Flow of System, Mechanism, and Procedure for Payment of 1 Year Taxes

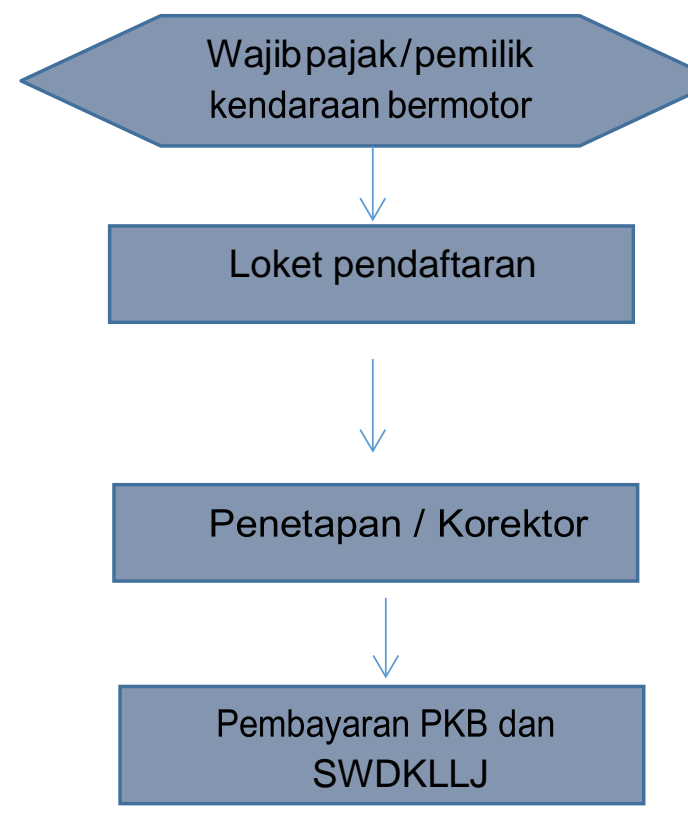

Penyerahan STNK yang telah disahkan, bukti pembayaran

PKB, dan SWDKLLJ serta stiker kartu dana SWDKLLJ

\section{Wajib pajak/pemilik}

kendaraan bermotor

Sumber : Kantor Pelayanan Pajak 2019 
Web Jurnal Online: jurnal.unmuhjember.ac.id

By: Salmawati; Dian Eka Rahmawati; Anang Setiawan

The Role of Argomoulyo Village Samsat in Breaking Taxpayer Density

in Bantul KPPD 2017-2018

\section{b. Year Tax Payment Mechanism Requirements}

To make 1 year tax payment is to bring a STNK and BPKB (original and photocopy) and some personal identifications as follows:

a) Individual: Valid self-identity (KTP, SIM, Passport) and for those who are unable to attach sufficient stamped power of attorney.

b) Legal entity: A copy of the deed of establishment, domicile statement, stamped power of attorney sufficiently signed by the leader and affixed with the stamp of the legal entity concerned.

c) Government agencies (including BUMN and BUMD): Letter of assignment or sufficiently sealed power of attorney signed by the leader and affixed with the stamp of the relevant agency.

\section{Systems, Mechanisms and Procedures}

a) Form filling: Taxpayers or motorized vehicle owners fill in motorized vehicle data on the form provided.

b) Vehicle physical check: Taxpayers or motorized vehicle owners carry motorized vehicles along with completeness documents (invoices and supporting files) to the physical check section to check and swipe the frame number and machine number of each sheet.

c) PNBP payments: Taxpayers or motorized vehicle owners pay PNBP (BPKB, STNK, and TNKB) and receive proof of PNBP payment.

d) Registration: Taxpayers or motorized vehicle owners submit vehicle documents equipped with a physical check form, STNK application form and register number (police number) that has been obtained from the BPKB section to the registration section for investigation.

e) Data recording: Officers perform data recording in accordance with motorized vehicle documents from the obligatory or motorized vehicle owner on the data base.

f) Determination of PKB and SWDKLLJ: The assignment officer informs and determines the amount of PKB and SWDKLLJ.

g) PKB and SWDKLLJ Payments: Taxpayers or motorized vehicle owners pay BBNKB, PKB and SWDKLLJ according to the amount stipulated to the payment officer and receive proof of payment.

h) Officers print vehicle registration: Officers print vehicle registration according to the data record of motorized vehicles and submit to the delivery officer.

i) TNKB Printing: Officers print the TNKB in accordance with the recorded vehicle data and submit it to the delivery officer.

j) Submission of STNK and PKB: Taxpayers or motorized vehicle owners receive STNK and TNKB from surrender officers. 
Page 628-646 ISBN: 978-602-6 988-75-1

Web Jurnal Online: jurnal.unmuhjember.ac.id By: Salmawati; Dian Eka Rahmawati; Anang Setiawan The Role of Argomoulyo Village Samsat in Breaking Taxpayer Density in Bantul KPPD 2017-2018

Image 3.2

System Flow, Mechanism, and Procedure for Payment of 5 Years Tax

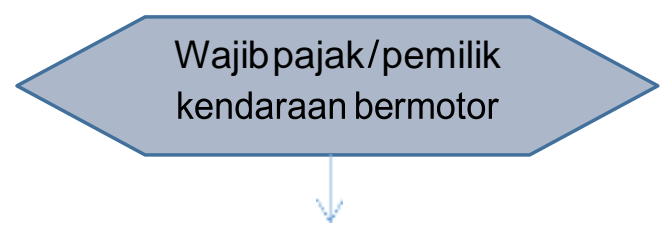

Permohonan Layanan

(Pengisian Formulir)

\section{Cekfisikkendaraanbermotor}

Pembayaran PNBP (BPKB,

STNK, dan TNKB)

Pendaftaran

Pendaftaran BPKB

(Polda/Polres)

Perekaman data

Penetapan /

korektor

Penyerahan bukti pembayaran BBNKB, PKB, dan

SWDKLLJ serta stiker kartu dana SWDKLLJ

PembayaranBBNKB, PKB, dan

SWDKLLJ

Pencetakan STNK

Pencetakan TNKB

Penyerahan BPKB, STNK, dan

TNKB

Wajib pajak/pemilik

kendaraan bermotor 
Proceeding ICOGISS 2019

Page 628-646 ISBN: 978-602-6 988-75-1

Web Jurnal Online: jurnal.unmuhjember.ac.id

By: Salmawati; Dian Eka Rahmawati; Anang Setiawan

The Role of Argomoulyo Village Samsat in Breaking Taxpayer Density

in Bantul KPPD 2017-2018

\section{CONCLUSION}

5.1 The implementation of village Samsat, especially the Argomulyo Village Samsat, Bantul Regency, Special Region of Yogyakarta has been considered successful in breaking down the queue of taxpayers in the main Bantul Samsat located in the Regional Tax Service Office. In 2018 to 2019 , there has been very little public order of taxpayers in the main Samsul Bantul, coupled with the transfer of tax payment locations in new buildings in 2019.

5.2 Village Samsat who acts as the organizer of the one-year renewal tax payment is considered to be able to reach the community. The operation of Samsomulyo Village Samsat for 1 year received a quite drastic figure in motor vehicle tax receipts, which amounted to Rp 602,183,600.00 with a total number of motorized vehicles totaling 1,905 at the end of December 2018.

5.3 Information dissemination carried out by the Regional Tax Service Office, namely in collaboration with Spot Radio, Radio Persatuan Bantul, advertising, and assistance to village websites had a positive impact on the development of village Samsat. Village Samsat is increasingly recognized by the surrounding community and chooses to pay a one-year renewal tax in the village Samsat because the village samsat has been distributed in several strategic locations so that the community can reach it. 
Proceeding ICOGISS 2019

Page 628-646 ISBN: 978-602-6 988-75-1

Web Jurnal Online: jurnal.unmuhjember.ac.id

By: Salmawati; Dian Eka Rahmawati; Anang Setiawan

The Role of Argomoulyo Village Samsat in Breaking Taxpayer Density

in Bantul KPPD 2017-2018

\section{REFERENCES}

Buku :

Agustino, L. (2014). Dasar-Dasar Kebijakan Publik. Bandung : Alfabeta.

Corbin, A. S. (2003). Dasar-Dasar Penelitian Kualtitatif. Yogyakarta: Pustaka Pelajar.

Dyah Mutiarin, R. R. (2015). Kualitas Pelayanan E-KTP di Kantor Kecamatan Dempo

Selatan Kota Pagar Alam Tahun 2015. Jurnal Ilmu Pemerintahan.

Indiahono, D. (2009). Kebijakan Publik Berbasis dynamic Policy Analysis.

Yogyakarta: Gava Media.

Nurmandi, A. (2010). Manajemen Pelayanan Publik. Yogyakarta: PT. Sinergi Visi Utama.

Purwanto, D. R. (2012). Implementasi Kebijakan Publik Konsep dan Aplikasinya di Indonesia. Yogyakarta: Gava Media.

Ritonga, I. T. (2009). Perencanaan dan Penganggaran Keuangan Daerah di Indonesia. Yogyakarta: Sekolah Pascasarjana UGM.

Salim, A. (2001). Teori dan Paradigma Penelitian Sosial. Yogyakarta: Tiara Wacana.

Soekanto, S. (2002). Sosiologi Suatu Pengantar. Jakarta: PT Raja Grafindo Persada.

Ratminto dan Atik Septi Winarsih (2005). Manajemen Pelayanan : Pengembangan Model Konseptual , Penerapan Citizen's Charter dan Standar Pelayanan Minimal. Yogyakarta: Pustaka Pelajar.

Jurnal :

Amri, Pahmi dan Pribadi, Ulung. 2015. Implementasi Pelayanan Samsat Corner dlm Rangka Meningkatkan Pelayanan Pajak Kendaraan Bermotor Tahun 2014. Jurnal Ilmu Pemerintahan dan Kebijakan Publik. Volume 2, Nomor 2.

Ulfa, Ellis Fedya dan Meirinawati. 2015. Inovasi Layanan Samsat Walk Thru Sebagai Wujud Pelayanan Prima Di Kantor Bersama Samsat Mojokerto. Jurnal Administrasi Negara. Volume 1, Nomor 1.

Bahari, dkk. 2012. Penerapan Sistem Administrasi Manunggal Satu Atap (Samsat) DriveThru dalam Meningkatkan Pelayanan Publik (Studi Pada Kantor Bersama Samsat Kabupaten Lamongan). Jurnal Administrasi Publik. Volume 1, Nomor 4.

Ardiani, dkk. 2016. Implementasi Layanan Inovasi Samsat Keliling Dalam Upaya Meningkatkan Pelayanan Pembayaran Pajak Kendaraan Bermotor (Studi Pada Kantor 
Proceeding ICOGISS 2019

Page 628-646 ISBN: 978-602-6 988-75-1

Web Jurnal Online: jurnal.unmuhjember.ac.id

By: Salmawati; Dian Eka Rahmawati; Anang Setiawan

The Role of Argomoulyo Village Samsat in Breaking Taxpayer Density

in Bantul KPPD 2017-2018

Bersama Samsat Kabupaten Tulungagung). Jurnal Perpajakan. Volume 9, Nomor 1.

Katrina, Devi Rahma dan Meirinawati. 2016. Inovasi Pelayanan Program Kerja Online Malam (Kolam) Pada Kantor Bersama Sistem Administrasi Manunggal Satu Atap (Samsat) Kabupaten Nganjuk. Jurnal Administrasi Negara. Volume 1, Nomor 1.

Dompak, Timbul dan Supratama, Naufal Alfian. Pengaruh Inovasi Dan Kualitas Pelayanan Terhadap Kepuasan Masyarakat Pengguna Layanan Samsat Drive Thru. Jurnal Dialektika Publik. Volume 3. Nomor 1.

Djumiarti, dkk. Inovasi Pelayanan Publik Pada Kantor Samsat Kota Tegal (Studi Kasus Pada Pajak Kendaraan Bermotor)

Fitrianti, Pramita Dwi, Rochmah, Siti, dan Hanafi, Imam. Pelaksanaan Program Inovasi Samsat CornerDalam Rangka Meningkatkan Pelayanan Kepada Wajib Pajak (Studi Pada Samsat Corner Kota Malang). Jurnal Administrasi Publik (JAP). Volume 2. Nomor 2.

Subroto, Djoko dan Yamit, Zulian. 2014. Pengaruh Kinerja Pelayanan Aparatur Kepolisian Terhadap Kepuasan Masyarakat (Studi Kasus Pada Bagian Pengurusan Surat Ijin Mengemudi (SIM) Di Wilayah Kerja Kepolisian Republik Indonesia Resort Sleman

Polda Daerah Istimewa Yogyakarta). Jurnal Bisnis Dan Manajemen. Volume 7. Nomor 1.

Profil Kantor Pelayanan Pajak Daerah Di Kabupaten Bantul Dinas Pendapatan, Pengelolaan Keuangan Dan Aset Daerah Istimewa Yogyakarta

\section{Undang-undang :}

Keputusan Menteri Pendayagunaan Aparatur Negara Nomor 63 Tahun 2003 tentang Pedoman Pelayanan Publik

Undang-Undang Nomor 28 Tahun 2009 tentang Pajak Daerah dan Retribusi Daerah UndangUndang Nomor 25 Tahun 2009 tentang Pelayanan Publik

Peraturan Presiden $\quad$ Republik Indonesia Nomor 5 Tahun 2015 Tentang Penyelenggaraan Sistem Administrasi Manunggal Satu Atap Kendaraan Bermotor Peraturan Daerah No. 6 Tahun 2008 Tentang Organisasi dan Tatakerja Dinas Daerah Provinsi Daerah Istimewa Yogyakarta

Profil Kantor Pelayanan Pajak Daerah Di Kabupaten Bantul Dinas Pendapatan, Pengelolaan Keuangan Dan Aset Daerah Istimewa Yogyakarta 
Proceeding ICOGISS 2019

Page 628-646 ISBN: 978-602-6 988-75-1

Web Jurnal Online: jurnal.unmuhjember.ac.id

By: Salmawati; Dian Eka Rahmawati; Anang Setiawan

The Role of Argomoulyo Village Samsat in Breaking Taxpayer Density

in Bantul KPPD 2017-2018

\section{Website :}

http://web.jogjaprov.go.id/warga/catatan-sipil/view/samsat-desa-- inovasi-layanankesamsatan, diakses pada 28 Juni 2018

http://argomulyo.bantulkab.go.id, diakses pada 12 Desember 2018

https://bapenda.jabarprov.go.id/2017/04/04/yuk-mengenal-samsat/, diakses pada 19 Desember 2018

https://jasaraharja.co.id/berita/info-utama/pt-jasa-raharja-persero-cabang-d-iyogyakarta-gabung-tim-satgas-samsat-bantul.html, diakses pada 11 Januari 2019

(http://bpddiy.co.id/index.php?page=berita\&id=375), diakses pada 11 Januari 201 